\title{
SOCIOECONOMIC INFLUENCE OF TOBACCO USE AND DENTAL CARIES EXPERIENCE IN DIFFERENT MALE CROATIAN POPULATIONS
}

\author{
Tomislav Badel ${ }^{1}$, Ivana Savić Pavičin ${ }^{2}$, Krešimir Bašićc ${ }^{3}$ and Vanja Bašić Kes ${ }^{4}$ \\ ${ }^{1}$ Department of Removable Prosthodontics, School of Dental Medicine, University of Zagreb, Zagreb, Croatia; \\ ${ }^{2}$ Department of Dental Anthropology, School of Dental Medicine, University of Zagreb, Zagreb, Croatia; \\ ${ }^{3}$ Department of Pharmacology, School of Dental Medicine, University of Zagreb, Zagreb, Croatia; \\ ${ }^{4}$ Department of Neurology, Sestre milosrdnice University Hospital Centre, University of Zagreb, Zagreb, Croatia
}

SUMMARY - The purpose was to evaluate dental caries experience in different male subpopulations of Croatian Army recruits and dental students, and subsequently, smoking habits related to the level of education and place of residence. Croatian army recruits $(n=248$; mean age 20.2) and male dental students ( $\mathrm{n}=56$; mean age 21.5) were evaluated according to DMFT and FST indices, divided according to age and place of residence, and interviewed about their dietary habits and smoking of tobacco. In the subpopulation of recruits, the median value of DMFT was 6 and of FST index 25. A statistically significant difference was recorded between DT and FST index $(\mathrm{p}<0.05)$ according to dietary role of carbohydrates reflected in caries development. The number of recruits with finished elementary school coming from a rural area who smoked (in total $57.66 \%$ of smokers) was significantly larger $(\mathrm{p}=0.0041)$. In dental students, the median value of DMFT was 5 , with statistical significance in comparison with recruits $(\mathrm{p}=0.03)$. There was a difference in FST index (median 28) $(p<0.0001)$. Students were mostly nonsmokers $(71.43 \%)$ and had urban residence $(p<0.0001)$. FST index was a more specific indicator in the socioeconomically heterogeneous sample of recruits (more subjects coming from rural areas and with a lower level of education) than in the sample of dental students (more subjects coming from urban areas).

Key words: Dental caries; Prevalence; Tobacco smoking; Croatia

\section{Introduction}

Smoking is a public health issue, not only from the lung cancer, cardiovascular and cerebral disease point of view, but also as a significant oral health risk ${ }^{1,2}$. Epidemiological data on the prevalence of smokers in the United States reveal an average of $20.6 \%$ of smokers in the adult population ${ }^{3}$. In Croatia, the prevalence of smokers was researched in general population and in a population of high-school students ${ }^{4-8}$. There is a strong

Correspondence to: Ivana Savić Pavičin, DMD, PhD, Department of Dental Anthropology, School of Dental Medicine, University of Zagreb, Gundulićeva 5, HR-10000 Zagreb, Croatia

E-mail: savic@sfzg.hr

Received November 25, 2013, accepted January 15, 2018 socioeconomic connection among the subpopulations of smokers ${ }^{3,5,9}$.

During the 1990s, caries prevalence had a downward trend in developed countries, but the latest studies reveal a global increase due to pronounced etiologic socioeconomic factors ${ }^{10}$. However, caries prevalence was highest in lower socioeconomic strata and in different population subgroups such as recruits ${ }^{11-23}$, adolescents ${ }^{24,25}$, and students ${ }^{26,27}$.

The aim of this study was to evaluate dental caries experience of male Croatian Army recruits, and subsequently, their smoking habits. They were compared with male dental students. Apart from the study of caries in the recruit population and its relation to smoking $^{28,29}$, the relationship between caries and smoking 
and socioeconomic circumstances ${ }^{29}$ is rarely researched. Since caries is related to smoking, which is common in the recruit population ${ }^{30}$, this study examined the relation between smoking and socioeconomic circumstances the recruits come from, primarily their education, dietary habits, and rural or urban place of residence. Also, difference between smokers and nonsmokers regarding their oral hygiene habits was examined.

\section{Subjects and Methods}

A group of male Croatian Army recruits (mean age \pm standard deviation (SD) $20.1 \pm 2.28$, ranging from 18 to 29 years) were clinically observed and evaluated in 2000 at a dental office in Koprivnica barracks (northwest Croatia) during a systematic medical checkup. The second group consisted of 56 male dental students from $1^{\text {st }}$ to $4^{\text {th }}$ study year at the School of Dental Medicine, University of Zagreb (mean age \pm SD $21.5 \pm 1.65$, ranging from 19 to 25 years), selected from practical study groups. All participants gave their informed consent prior to enrolment in the study.

Caries experience of recruits was diagnosed by standard dental instruments and diagnostic light and Kuhhorn probe. Different effects of dental caries experience on oral health were described by the FST index (number of filled (F) and sound (S) teeth (T)) and DMFT index (number of decayed (D), missing (M) and filled (F) teeth (T)). This clinical classification includes diagnosed caries lesions (D) with cavitations $\left(\mathrm{D}_{2-4}\right)$ that can be identified by probing. Initial lesions were not considered ${ }^{31,32}$. Wisdom teeth were not examined. The study included recruits who had no caries experience $(\mathrm{DMFT}=0)$. No radiographs were taken because the $\mathrm{x}$-ray diagnostics was only accessible in the public hospital of Koprivnica. All subjects were divided according to age and place of residence (urban or rural $)^{33}$. They were also interviewed about their dietary habits (consumption of sugar - yes, no), daily number of tooth brushing $(1,2,3$, or $>3)$, reason to visit the dentist during a year (regularly, irregularly) and smoking of tobacco (yes, no). Level of education (elementary school, high school, and university level) was only recorded in recruits.

Statistical analysis was performed by using the STATISTICA statistical software and the following statistical methods: $\chi^{2}$-test, Kruskal-Wallis test, Fisher exact test, Spearman correlation coefficients, and logistic regression. Differences were considered statistically significant at the level of $\mathrm{p}<0.05$.

The reliability of the results was tested by random selection of 30 recruits from this study for repeat examination by two researchers (T.B. and I. S. P.). The intra-examiner and inter-examiner agreements were evaluated by Cohen kappa index ( $\kappa=0.75-0.84)$. Follow-up examination was carried out after a certain period and the examiners were not informed about the results of the first oral examination of recruits.

Test differences in the DMFT and FST indices among the subgroups according to the living area, age, consumption of sugar, smoking habit of recruits, and daily number of tooth brushings of recruits were examined by use of Kruskal-Wallis test. Comparison between living areas of recruits with smoking habit and level of education was performed by the $\chi^{2}$-test and the reason to visit the dentist during a year by Fisher exact test. Spearman correlation coefficients were used to compare numerical variables, i.e. age of recruits, DMFT index with its derivative, FST index, and daily number of tooth brushings. Test differences in the DMFT index depending on smoking habit of recruits were examined by the analysis of variance. The relation between the living area and the level of education as predictor variables for smoking habit of recruits was analyzed using logistic regression. Kruskal-Wallis test was used on comparison of DMFT and FST indices between recruits and students. The $\chi^{2}$-test was used to compare living area of recruits with smoking habit and reason to visit the dentist during a year.

\section{Results}

The median value of DMFT was 6 (Fig. 1, Table 1) and of FST index 25 (Fig. 2, Table 1). Only 4\% of recruits never experienced caries (DMFT $=0)$. Correlation analysis (Spearman correlation coefficients) did not show statistically significant correlation between age and DMFT index and its derivatives. Positive correlation between DT and MT $(\mathrm{p}<0.001)$ and negative correlation between FT and DT ( $\mathrm{p}=0.0009)$ were recorded within certain indices on the basis of DMFT index. There was no statistically significant correlation between DMFT and FST indices and daily number of tooth brushing. 




Fig. 1. Distribution of DMFT index in the sample of recruits $(D M F T=$ number of decayed $(D)$, missing $(M)$ and filled $(F)$ teeth $(T)$ ).

Table 1. Comparison of recruits with smoking habit according to living areas

\begin{tabular}{|l|l|l|l|}
\hline Living area & $\begin{array}{l}\text { Smoking - yes } \\
(\mathrm{n}, \%)\end{array}$ & $\begin{array}{l}\text { Smoking - no } \\
(\mathrm{n}, \%)\end{array}$ & $\begin{array}{l}\text { Total } \\
(\mathrm{n}, \%)\end{array}$ \\
\hline Urban & 78 & 59 & 137 \\
& $56.93 \%$ & $43.07 \%$ & $100.0 \%$ \\
& $31.45 \%$ & $23.79 \%$ & $55.24 \%$ \\
\hline Rural & 65 & 46 & 111 \\
& $58.56 .0 \%$ & $41.44 \%$ & $100.0 \%$ \\
& $26.21 \%$ & $18.55 \%$ & $44.76 \%$ \\
\hline Total & 143 & 105 & 248 \\
& $57.66 \%$ & $42.34 \%$ & $100.0 \%$ \\
\hline
\end{tabular}

No connection ( $p>0.05)$ was found between smoking and DMFT, DT, MT, FT and FST indices in recruits. There was no difference in smoking habits according to the age of recruits $\left(\chi^{2}\right.$-test $\left.=2.7052 ; p=0.100\right)$, and the reason to visit the dentist during a year (Fisher exact test, $\mathrm{p}=0.0701)$. There was no statistically significant difference between living areas of recruits with smoking habit $\left(\chi^{2}\right.$-test $\left.=0.066 ; \mathrm{p}=0.7969\right)$ (Table 1$)$. Comparison between the levels of education of recruits with smoking habit revealed a statistically significant difference $\left(\chi^{2}\right.$-test $\left.=11.698 ; \mathrm{p}=0.0029\right)$ (Table $2)$. However, the number of recruits with finished ele-

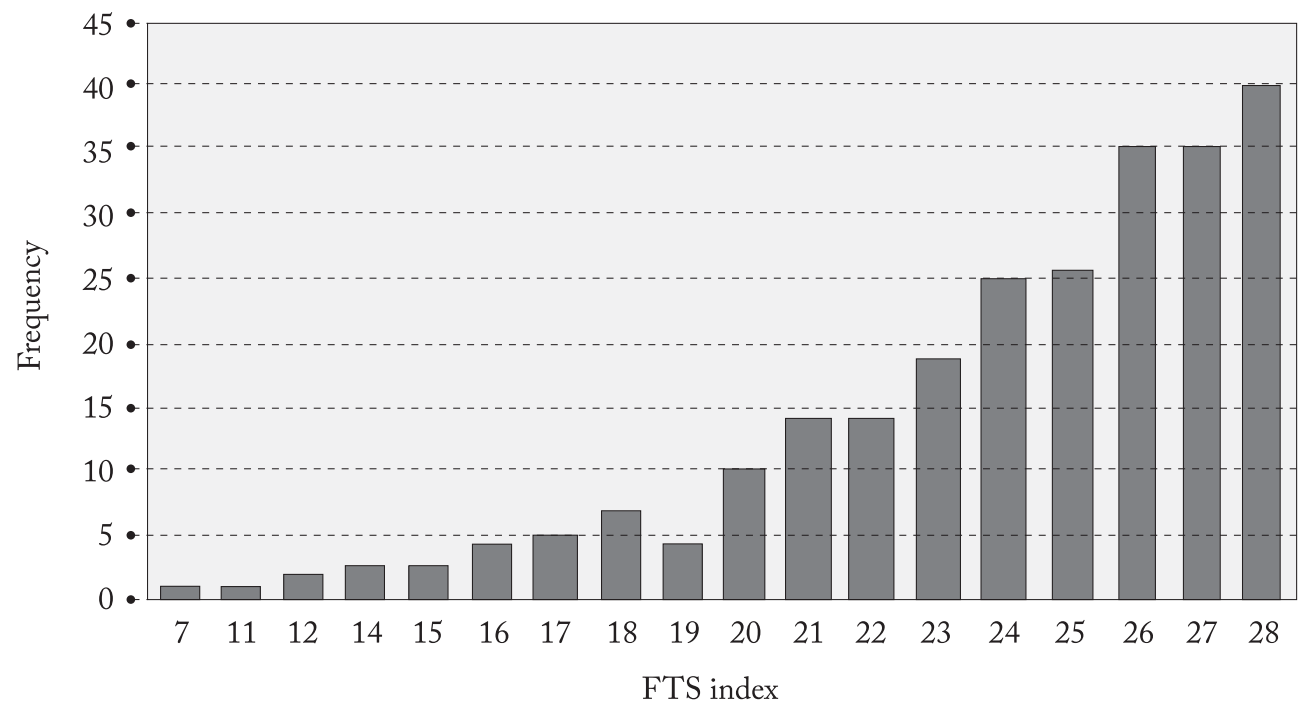

Fig. 2. Distribution of FST index in the sample of recruits $(F S T=$ number of filled $(F)$ and sound (S) teeth (T)). 
Table 2. Comparison of recruits with/without smoking babit according to the level of education

\begin{tabular}{|l|l|l|l|l|}
\hline Variable & $\begin{array}{l}\text { Elementary } \\
\text { school } \\
(\mathrm{n}, \%)\end{array}$ & $\begin{array}{l}\text { High } \\
\text { school } \\
(\mathrm{n}, \%)\end{array}$ & $\begin{array}{l}\text { University } \\
\text { degree } \\
(\mathrm{n}, \%)\end{array}$ & $\begin{array}{l}\text { Total } \\
(\mathrm{n}, \%)\end{array}$ \\
\hline Smoking & 42 & 95 & 6 & 143 \\
- yes & $29.37 \%$ & $66.43 \%$ & $4.20 \%$ & $100.0 \%$ \\
& $16.94 \%$ & $38.31 \%$ & $2.42 \%$ & $57.66 \%$ \\
\hline Smoking & 13 & 82 & 10 & 105 \\
- - no & $12.38 \%$ & $78.10 \%$ & $9.52 \%$ & $100.0 \%$ \\
& $5.24 \%$ & $33.06 \%$ & $4.03 \%$ & $42.34 \%$ \\
\hline Total & 55 & 177 & 16 & 248 \\
& $22.18 \%$ & $71.37 .7 \%$ & $6.45 \%$ & $100.0 \%$ \\
\hline
\end{tabular}

Table 3. Comparison of recruits with/without smoking habit according to dietary habits (sugar consumption)

\begin{tabular}{|l|l|l|l|}
\hline Variable & $\begin{array}{l}\text { Sugar - yes } \\
(\mathrm{n}, \%)\end{array}$ & $\begin{array}{l}\text { Sugar - no } \\
(\mathrm{n}, \%)\end{array}$ & $\begin{array}{l}\text { Total } \\
(\mathrm{n}, \%)\end{array}$ \\
\hline Smoking - yes & 41 & 102 & 143 \\
& $28.67 \%$ & $71.33 \%$ & $100.0 \%$ \\
& $16.53 \%$ & $41.13 \%$ & $57.66 \%$ \\
\hline Smoking - no & 37 & 68 & 105 \\
& $35.24 \%$ & $64.76 \%$ & $100.0 \%$ \\
& $14.92 \%$ & $27.42 \%$ & $42.34 \%$ \\
\hline Total & 578 & 170 & 248 \\
& $31.45 \%$ & $68.55 \%$ & $100.0 \%$ \\
\hline
\end{tabular}

mentary school coming from a rural area who smoked was significantly larger (logistic regression odds ratio $(\mathrm{OR})=7.076 / 95 \%$ confidence interval $(95 \% \mathrm{CI}) 1.858$ 26.955; $\mathrm{p}=0.0041$ ).

There was a statistically significant difference for recruits who smoked in DT (Kruskal-Wallis test= $7.9527(\mathrm{df}) 2 ; \mathrm{p}=0.0188$ ) and FST (Kruskal-Wallis test $=10.9526(\mathrm{df}) 2 ; \mathrm{p}=0.0042)$ indices according to the level of education. There were no differences in DT and FST indices for nonsmokers ( $p>0.05)$. Also, smokers showed a statistically significant difference in DT (Kruskal-Wallis test $=4.2851$ (df) $1 ; \mathrm{p}=0.0384$ ) and FST (Kruskal-Wallis test $=4.1237(\mathrm{df}) 1 ; \mathrm{p}=0.0423$ ) indices according to dietary role of carbohydrates reflected in caries development. Again, there was no statistically significant difference in nonsmokers.

Recruits who smoked did not consider the consumption of sugar more irrelevant to oral health $\left(\chi^{2}-\right.$ test=1.211; $\mathrm{p}=0.2711$ ) (Table 3). There was no difference in daily number of teeth brushing between smoking and nonsmoking recruits (Kruskal-Wallis test $=0.0021$ (df1); $p=0.9638$ ). There was no statistically significant difference $\left(\chi^{2}\right.$-test $\left.=3.362 ; \mathrm{p}=0.0667\right) \mathrm{ac}-$ cording to the reason to visit the dentist per year.

Comparison of recruits and students showed a statistically significant difference in DMFT and FST indices (Table 4). Only $12.5 \%$ of students never experi-

Table 4. Comparison of values of DMFT and FST indices between recruits and dental students $\left(Q_{1}=25 \%, Q_{2}=75 \%\right)$

\begin{tabular}{|c|c|c|c|c|c|}
\hline Variable & Minimum & $Q_{1}$ & Median & $Q_{2}$ & Maximum \\
\hline DMFT - recruits & 0 & 4 & 6 & 10 & 22 \\
\hline DMFT - students & 0 & 2 & 5 & 8 & 14 \\
\hline \multicolumn{6}{|c|}{ Kruskal-Wallis test $=4.6687(\mathrm{df}) 1 ; \mathrm{p}=0.0307$} \\
\hline DT - recruits & 0 & 1 & 2 & 4 & 14 \\
\hline DT - students & 0 & 0 & 0 & 0 & 3 \\
\hline \multicolumn{6}{|c|}{ Kruskal-Wallis test $=67.5544, \mathrm{df}(1) ; \mathrm{p}<0.0001$} \\
\hline MT - recruits & 0 & 0 & 1 & 2 & 13 \\
\hline MT - students & 0 & 0 & 0 & 0 & 4 \\
\hline \multicolumn{6}{|c|}{ Kruskal-Wallis test $=30.1880,(\mathrm{df}) 1 ; \mathrm{p}<0.0001$} \\
\hline FT - recruits & 0 & 0 & 2 & 5 & 19 \\
\hline FT - students & 0 & 2 & 5 & 8 & 14 \\
\hline \multicolumn{6}{|c|}{ Kruskal-Wallis test $=13.4869, \mathrm{df}(1) ; \mathrm{p}=0.0002$} \\
\hline FST - recruits & 7 & 22 & 25 & 27 & 28 \\
\hline FST - students & 24 & 28 & 28 & 28 & 28 \\
\hline
\end{tabular}

$\mathrm{Q}=$ quantile; DMFT = number of decayed $(\mathrm{D})$, missing $(\mathrm{M})$ and filled $(\mathrm{F})$ teeth $(\mathrm{T}) ; \mathrm{FST}=$ number of filled $(\mathrm{F})$ and sound $(\mathrm{S})$ teeth $(\mathrm{T})$ 
enced caries (DMFT $=0)$. While the mean percentage of treated teeth in recruits was $49 \% \pm 37 \%$, it was as high as $94.3 \% \pm 17.8 \%$ in students (Kruskal-Wallis test $=114.8045(\mathrm{df}) 1 ; \mathrm{p}<0.0001)$. As much as $28.2 \%$ of recruits had completely untreated teeth (healed teeth $0 \%$, and only $18.6 \%$ had completely treated teeth (healed teeth 100\%). On the contrary, only one student (1.9\%) did not have treated teeth and $75 \%$ of them had completely treated teeth. The share of students (85.7\%) coming from an urban place of residence as compared to recruits $(45.1 \%)$ was statistically significant $\left(\chi^{2}-\right.$ test=17.8076; $\mathrm{p}<0.0001)$.

Unlike recruits who mostly (68.6\%) did not consider sugar consumption relevant to oral health, a significantly smaller share of students considered it to be true $(10.7 \%)\left(\chi^{2}\right.$-test $\left.=62.6843 ; \mathrm{p}<0.0001\right)$. The share of recruits who were smokers $(57.7 \%)$ was significantly larger than the share of students (28.6\%), which also yielded a statistically significant difference $\left(\chi^{2}\right.$-test= 15.4964; $\mathrm{p}<0.0001)$.

\section{Discussion}

Oral health is related to nicotinism (principally cigarette smoking) and includes various dental diseases (e.g., periodontal diseases, caries and tooth loss, gingival recession) and oral diseases such as cancer and precancerous lesions ${ }^{2,34}$. Smoking is one of the leading risk factors for stroke, and it does not spare younger population ${ }^{35}$. Tobacco habits are considered risk factors for caries development ${ }^{2}$.

Taking into account the fact that contemporary Croatia is a country with characteristics of socioeconomic transition, more smokers and more caries in various groups of general population are to be expected. Studies in young people such as medical students found the prevalence of smokers in 1989/2000 to be $29 \% / 31 \%$. A very high prevalence of smokers of $55.8 \%$ was found in a population of high-school students $^{7}$. Zajc et al. ${ }^{30}$ found close correlation $(\mathrm{p}<0.001)$ between recruits who were smokers (63.8\% of sample) and dental readiness for combat.

Epidemiological data from Croatia show variable prevalence of smokers (between 23\% and 32\%) in different regions ${ }^{4}$. Results of the epidemiological study of smoking prevalence in Croatia from 2003 showed 24\%$33 \%$ of male smokers and $10 \%-21 \%$ of female smokers, depending on the region ${ }^{8}$. The prevalence of heavy smoking in Croatia depended on gender (male), age (35-64), low education, migrations during the war, etc. ${ }^{5}$.

Military recruits were researched in many countries worldwide from the aspect of general population oral health. Results revealed the mean value of DMFT index of 8.06 for draft registrants in federal republics of former Yugoslavia (7.64 in rural subjects and 8.52 in urban subjects). For Croatian recruits, DMFT value was 8.41 (DT: 3.87, MT: 1.15 and FT: 3.39) and was higher in urban environment as compared with subjects living in rural environment (8.54 vs. 8.2; DMFT: 8.2 $)^{11}$. Our study from 1998 established a median value of 7 for DMFT index for Croatian recruits from Koprivnica $^{12}$. Škec et al. ${ }^{14}$ examined oral health of the Croatian Army recruits and professional soldiers. They found DT of 5.84 per recruit and 2.71 per professional. Only $1.53 \%$ of study subjects had DMFT $=0$.

In 2008, caries was found to have increased (DMFT value: 4.1) in Australian recruits aged 17-30 (previously recorded DMFT was 3.8) ${ }^{15}$. In Danish recruits, a $63 \%$ decrease of caries was recorded between 1972 and 1993 (DMFT 6.2. in 1993) ${ }^{16}$. In German recruits, the mean DMFT index was $7.5^{17}$. In Italian recruits, the mean DMFT was $7.14^{18}$. Campos et al. ${ }^{19}$ confirmed correlation between dental caries and smokers in a sample of Italian adults attending Military Academy. Caries of dental surface ranged from 0.6 in the nonsmoker subgroup to 1.1 in heavy smokers. Also, the share of subjects without caries experience was $15.9 \%$, which is not only higher from our sample of recruits but also from our sample of dental students. In Norwegian recruits, caries decrease to DMFT value of 10.2 was revealed ${ }^{20}$. In a study including Swiss recruits, a DMFT value of 10.1 and 3.51 was established in 1985 and 2006, respectively ${ }^{21}$. In Royal Air Force recruits, caries decrease to DMFT 6.5 was found ${ }^{22}$. A study in Turkish recruits established a DMFT value of 6, with a significant relationship between DMFT value and sugar consumption ${ }^{23}$.

Although caries prevalence increased in Australian Navy recruits, it was found that the prevalence of Australian recruits with no caries experience (DMFT $=0$ ) was $20.5 \%$ for age $17-30^{15}$. We found $2.6 \%$ and $9.3 \%$ of Croatian recruits with no caries experience in 1998 and 2001, respectively ${ }^{12,13}$. In a population of 19-yearold Croatian male recruits, the DMFT value was 7.32. The subjects who did not smoke tobacco had less decayed teeth (DT index, $\mathrm{p}<0.001$ ) and more teeth with 
fillings and/or sound teeth (FT, $\mathrm{p}=0.005$ and FST, $\mathrm{p}=0.004)^{36}$.

Since caries has a permanent effect on oral health, comparisons with the adolescent population are possible; in Danish adolescents, DMFT was 2.03, and $38 \%$ of them never experienced caries $(\mathrm{DMFT}=0)^{24}$. The socioeconomic connection between caries onset and its effects on oral health was also determined in American students ${ }^{25}$. Two subpopulations (suburban area/downtown area) of Brazilian adolescents were shown to be similar: caries free $(\mathrm{DMFT}=0)(29.7 / 26.5)$, DMFT (3.01/2.95), and MT (0.05/0.01). A statistically significant difference was visible for DT $(1.22 / 0.37)$ and FT (1.67/2.52) values ${ }^{37}$. All indicators of caries showed higher DMFT values in our study, whereas similar values were obtained only in a population of dental students regarding DT, MT and FT indices.

In a population of Hungarian police students $(9.7 \%$ of females), it was determined that only $9.4 \%$ were caries free $(\mathrm{DMFT}=0)$, which is more than in our study. DMFT value was 10.3 , whereas DT was 7.8 and MT 1.6, i.e. higher as compared with our study; the FT value was lower (0.9), showing higher caries experience and less treated teeth as compared to our study $^{38}$.

In a French population of students, a lower DMFT value was recorded (mean value 4.4) compared to our study, while the share of smokers was approximately the same $27.6 \%$ of French compared to $28.65 \%$ of Croatian students in this study $)^{26}$. In a recent study of oral health in students at the University of Zagreb, Simat et al..$^{27}$ found the mean DMFT of 7.97 , with a higher value for males than females. Dental students had a mean DMFT of 6.96 and the non-dental student group had DMFT of 8.97.

In conclusion, as in other parts of the world, caries incidence was found to decrease in the population of the Croatian Army recruits. This study was the first in Croatia to relate caries experience to smoking in a heterogeneous socioeconomic group of recruits. In order to increase the efficiency, smoking as a feature related to dental status should be reduced. Smoking was shown to be more prominent in recruits of lower education, which was also seen worldwide ${ }^{28}$, but it did not depend on the living area, which other researchers did not investigate. Dietary habits and the method of oral hygiene were not different in smokers and nonsmok- ers, which was not considered in previous studies either. The index of filled and sound teeth (FST) is a more appropriate tool for describing variation in the population with higher caries experience, especially according to dietary role of carbohydrates. In comparison of recruits and dental students, $71.43 \%$ of the students were nonsmokers and had urban residence, whereas $57.66 \%$ of army recruits were smokers.

\section{Acknowledgment}

This study was carried out within the frame of the project entitled Orofacial Pain and Temporomandibular Disorders - A Long Term Follow-up, University of Zagreb, Zagreb, Croatia.

\section{References}

1. Čop-Blažić N, Zavoreo I. There is no healthy level of smoking. Acta Clin Croat. 2009;48:371-6.

2. de Araújo Nobre M, Maló P.Prevalence of periodontitis, dental caries, and peri-implant pathology and their relation with systemic status and smoking habits: results of an open-cohort study with 22009 patients in a private rehabilitation center. J Dent. 2017. pii: S0300-5712(17)30181-1. doi:10.1016/j. jdent.2017.07.013.

3. Sonoda C, Ebisawa M, Nakashima H, Sakurai Y. Dental caries experience, rather than toothbrushing, influences the incidence of dental caries in young Japanese adults. Community Dent Health. 2017;34(2):118-21. doi: :10.1922/CDH_4073Sonoda04.

4. Kovačić L, Gazdek D, Samardžić S. Croatian health survey: cigarette smoking. Acta Med Croat. 2007;61:281-5. (in Croatian)

5. Samardžić S, Pristaš I, Vuletić Mavrinac G. Characteristics of heavy smokers in Croatia. Coll Antropol. 2009;33(Suppl 1): 61-6.

6. Radić M, Benjak T, Dečković Vukres V, Rotim Ž, Filipović Zore I. Presentation of DMFT/DMFT index in Croatia and Europe. Acta Stomatol Croat. 2015;49:275-84. doi: 10.15644/ asc $49 / 4 / 2$

7. Lujo M, Meštrović M, Ivanišević Malčić A, Karlović Z, Matijević J, Jukić S. Knowledge, attitudes and habits regarding oral health in first- and final-year dental students. Acta Clin Croat. 2016;55:636-43. doi: 10.20471/acc.2016.55.04.15

8. Samardžić S, Vuletić Mavrinac G, Prlić A. Regional pattern of smoking in Croatia. Coll Antropol. 2009;33(Suppl 1):43-6.

9. Bagramian RA, Garcia-Godoy F, Volpe AR. The global increase in dental caries. A pending public health crisis. Am J Dent. 2009;21:3-8.

10. Elmer TB, Langford J, McCormick R, Morris AJ. Is there a differential in the dental health of new recruits to the British 
Armed Forces? A pilot study. Br Dent J. 2011;211:E18. doi: 10.1038/sj.bdj.2011.937.

11. Lobnik-Gomilšek B. Epidemiological examination and caries prevalence in conscripts in 1989, 1990, and 1991. Master's thesis. Zagreb: University of Zagreb, 1993. (in Croatian)

12. Badel Z, Azinović Z, Keros J, Dulčić N, Mehulić K. Caries of Croatian Army recruits. Acta Stomatol Croat. 2003;37:433-7.

13. Badel T, Keros J, Jerolimov V, Dulčić N, Restek-Despotušić S. Oral health of the Croatian Army recruits in 2001. Med Glas (Zenica). 2009;6:256-60.

14. Škec V, Špiček Macan J, Sušac M, Jokić D, Brajdić D, Macan D. Influence of oral hygiene on oral health of recruits and professionals in the Croatian Army. Mil Med. 2006;171:1006-9. doi: 10.7205/MILMED.171.10.1006

15. Hopcraft M, Yapp KE, Mahoney G, Morgan MV. Dental caries experience in young Australian Army recruits 2008. Aust DentJ.2009;54:316-22.doi:10.1111/j.1834-7819.2009.01156.x

16. Antoft P, Rambusch E, Antoft B, Christensen HW. Caries experience, dental health behaviour and social status - three comparative surveys among Danish military recruits in 1972, 1982 and 1993. Community Dent Health. 1999;16:80-4.

17. Klimek J, Ganss C, Alffen T. Incidence of caries, types of restoration, and fissure sealants among German recruits in 1992 and 1996. Dtsch Zahnärzt Z. 1999;54:317-20. (in German)

18. Polastri F, Cerato E, Gallesio C, Pancotti G. The oral health status in a sample of recruits from different regions of Italy. Minerva Stomatol. 1991;40:397-403. (in Italian)

19. Campus G, Cagetti MG, Senna A, Blasi G, Mascolo A, Demarchi $\mathrm{P}$, et al. Does smoking increase risk for caries? A crosssectional study in an Italian military academy. Caries Res. 2011;45:40-6. doi: 10.1159/000322852

20. Asmyhr O, Grytten L, Grytten J. Changing trends in caries experience among male military recruits in Norway. Community Dent Oral Epidemiol. 1994;22;206-7. doi: 10.1111/j.1600-0528.1994.tb01842.x

21. Menghini G, Steiner M, Thomet E, Rath C, Marthaler T, Imfeld T. Further caries decline in Swiss recruits from 1996 to 2006. Schweiz Monatssch Zahnmed. 2010;111:590-5.

22. Richardson PS, McIntyre IG. Dental treatment needs of a cohort of Royal Air Force recruits over 5 year. Community Dent Health. 1996;13:11-6.

23. Ceylan S, Acikel CH, Okcu KM, Kilic S, Tekbas OF, Ortakoglu K. Evaluation of the dental health of the young adult male population in Turkey. Mil Med. 2004;169:885-9. doi: 10.7205/MILMED.169.11.885

24. Cinar AB, Christensen LB, Hede B. Clustering of obesity and dental caries with lifestyle factors among Danish adolescents. Oral Health Prev Dent. 2011;9:123-30.

25. Polk DE, Weyant RJ, Manz MC. Socioeconomic factors in adolescents' oral health: are they mediated by oral hygiene be- haviors or preventive interventions? Community Dent Oral Epidemiol. 2010;38:1-9.

doi: 10.1111/j.1600-0528.2009.00499.x

26. Bou C, Miquel JL, Poisson P. Oral health status of 1500 university students in Toulouse, France. Odontostomatol Trop. 2006;29:29-33.

27. Šimat S, Mostračić K, Matijević J, Simeon P, Rošin Grget K, Jukić Krmek S. A comparison of oral status of the fourth-year students of various colleges at the University of Zagreb. Acta Stomatol Croat. 2011;45:177-83.

28. Byrappagari D, Mascarenhas AK, Chaffin JG. Association of caries and tobacco risk with dental fitness classification. Mil Med. 2006;171:415-9.

29. Oscarson N, Espelid I, Jönsson B. Is caries equally distributed in adults? A population-based cross-sectional study in Norway - the TOHNN-study. Acta Odontol Scand. 2017;28:1-7. doi: 10.1080/00016357.2017.1357080

30. Zajc I, Brajdić D, Biočić J, Bošan-Kilibarda I, Kopić V, Siber S, Macan D. The effect of tobacco use on oral health and dental readiness in the Croatian Army. J Addict Dis. 2011;30:159-68. doi: 10.1080/10550887.2011.554783

31. Dye BA, Li X, Lewis BG, Iafolla T, Beltran-Aguilar ED, Eke PI. Overview and quality assurance for the oral health component of the National Health and Nutrition Examination Survey (NHANES), 2009-2010. J Public Health Dent. 2014; 74:248-56. doi: 10.1111/jphd.12056

32. Ekbäck G, Ordell S, Palmetun-Ekbäck M, Ekbäck G, Unell L, Johansson AK. Reporting dental caries disease in longitudinal studies - a suggestion. Swed Dent J. 2016;40:173-9.

33. Croatian Bureau of Statistics. The Model for the Differentiation of Urban, Rural, and Semi-Urban Settlements in the Republic of Croatia. Methodological Guidelines 67. Zagreb: Croatian Bureau of Statistics Methodological Guidelines No. $67 ; 2011$

34. Rotim Z, Bolanča Z, Rogulj AA, Andabak M, Boras VV, Vrdoljak DV. Oral lichen planus and oral lichenoid reaction an update. Acta Clin Croat. 2015;54:516-20.

35. Bašić Kes V, Jurašić MJ, Zavoreo I, Lisak M, Jeleč V, Zadro Matovina L. Age and gender differences in acute stroke hospital patients. Acta Clin Croat. 2016;55:69-78. doi: 10.20471/ acc.2016.55.01.11.

36. Badel T, Savić Pavičin I, Jelinić Carek A, Šegović S. Dental caries experience and tobacco use in 19-year-old Croatian Army recruits. Coll Antropol. 2014;38:671-5.

37. Bastos RS, Carvalho ES, Xavier A, Caldana ML, Bastos JR, Lauris JR. Dental caries related to quality of life in two Brazilian adolescent groups: a cross-sectional randomised study. Int Dent J. 2012;62:137-43. doi: 10.1111/j.1875-595X.2011.00105.x

38. Faragó I, Nagy G, Márton S, Túry F, Szabó E, Hopcraft M, Madléna M. Dental caries experience in a Hungarian police student population. Caries Res. 2012;46:95-101. doi: $10.1159 / 000336390$ 
Sažetak

\section{SOCIOEKONOMSKI UTJECAJ UPOTREBE DUHANA I ISKUSTVO ZUBNOG KARIJESA U RAZLIČITIH HRVATSKIH POPULACIJA MUŠKARACA}

\section{T. Badel, I. Savić Pavičin, K. Bašići i V. Bašić Kes}

Svrha istraživanja je bila procijeniti iskustvo dentalnog karijesa u različitih populacija muškaraca: novaka Hrvatske vojske i studenata dentalne medicine, kao i naviku pušenja vezano za stupanj obrazovanja i prebivalište. Prema indeksima DMFT i FST evaluirani su novaci Hrvatske vojske ( $\mathrm{n}=248$, prosječne dobi 20,2 godina) i muški studenti dentalne medicine ( $\mathrm{n}=56$, prosječne dobi 21,5 godina) podijeljeni prema dobi i prebivalištu te intervjuirani vezano za njihove prehrambene navike $\mathrm{i}$ pušenje duhana. Medijan indeksa DMFT za novake bio je 6, a indeksa FST 25. Statistički značajna razlika zabilježena je između DT i FST indeksa $(p<0,05)$ s obzirom na ulogu prehrane ugljikohidratima vezano za razvoj karijesa. Bilo je značajno više ( $\mathrm{p}=0,0041)$ novaka koji puše te sa završenom osnovnom školom iz ruralnog područja (ukupno $57,66 \%$ pušača). Za studente dentalne medicine medijan indeksa DMFT je bio 5, sa statističkom značajnočću u usporedbi s novacima $(\mathrm{p}=0,03)$. Postojala je i razlika za indeks FST (medijan 28, p<0,0001). Studenti su većinom bili nepušači $(71,43 \%)$ i imali su urbano prebivalište $(\mathrm{p}<0,0001)$. Indeks FST bio je specifičniji indikator za socio-ekonomski heterogeni uzorak novaka (više ih je bilo s ruralnim prebivalištem i nižim stupnjem obrazovanja) nego kod studenata dentalne medicine (više ih je bilo s urbanim prebivalištem).

Ključne riječi: Dentalni karijes; Prevalencija; Duhan, pušenje; Hrvatska 